\title{
The Wise Worker
}

\begin{abstract}
In this chapter we consider the competence of older employees and how it has been developed and refined throughout their careers. We consider this competence in the light of earlier findings on the development of work-related knowledge and we suggest some new ways of interpreting the particular kind of competence older employees often have. We suggest that the concept of wisdom can be used to supplement our understanding of long career competence and based on our interview data we present a concept of the wise worker.
\end{abstract}

Keywords Wisdom · Experience $\cdot$ Age

The analysis of the findings in the previous chapter introduced some interesting issues, some of these are familiar, while others are perhaps less well defined. In this chapter we will attempt to improve these definitions and develop a concept. We begin by considering our findings in relation to the literature and earlier studies which we discussed in Chapters 2 and 3 , and we summarise our understanding of the mature worker in terms of learning and competence. We then go a step further and attempt to supplement these descriptions by introducing the concept of the wise worker.

In Chapter 2 we presented some concepts of competence and knowledge at work. The findings from our interviews are interesting in relation

(C) The Author(s) 2021 
to earlier work on situated knowledge and professional knowledge and to a certain extent to the work on organisational knowledge. With regard to the latter, the questions we posed in interviews were more related to the individual and their colleagues, rather than the organisation. However, we did find examples which fit in well with Lundvall's model (1996). We found many examples of "knowing why", or perhaps we should say remembering why. Remembering why we reorganised our working tasks, why we bought that ICT system, why one project failed or the other succeeded. "Knowing how" was also referred to often, however this definition does not really convey the importance of what we found. Of course, our interviewees knew how to do their jobs and many other things as well, but they knew how to do their jobs in more than one way. "Know-who" was very important to many of our interviewees, indeed almost everyone we spoke to mentioned the importance of conferring with colleagues, not only to get information from them as Lundvall suggests, but also to discuss alternatives with them or to share tasks with them. We also found examples of "knowing what" and we assume that much of this is based on formal education or subsequent training. We did however find some examples which might be better classified as "remembering what", such as remembering where the cables under the building go, when the drawings have been lost. When focusing on the age or long experience of the people in our case studies, many nuances of Lundvall's model became evident which are not explicitly present in the model. We also found that some of the forms of knowing, suggested by Antonacopoulou (2006) helped us to describe and understand what our interviewees were telling us. "Knowing by storing and by repeating", featured strongly in our cases. We found this to be typical of practicebased learning over time where the old ways of doing things were stored and compared with the new ones and repetitive activities were fine-tuned over time to become an integrated part of the individual's repertoire. We also found examples of knowing by reflecting, questioning, synthesising and improvising.

Perhaps the most valuable knowledge we found among our over 50s, was what we could classify as situated knowledge, indeed much of what we have defined as senior competence may have limited value outside their current work situation. This might be the ability to deal with a particular type of situation such as an organisation which is not following the rules or how to know whose best practice really is the best, based on past experience or how to communicate complex information to a particular group of people. We also observed that the experiences which shaped 
this learning were often specific to one organisation or one workplace and were often developed to counteract some weakness, such as a badly functioning ICT system, or lack of resources.

Not everyone interviewed was a member of a profession, but we found that their descriptions of how they worked bore a close resemblance to Eraut's (2000) descriptions of how professionals learn, i.e. by exchanging viewpoints with colleagues or discussing previous experiences. Eraut (1994) also mentions something which we found frequently, that is, how repeated activities might result in different meanings being generated depending on the context. We did not examine relationships to formal knowledge; however, our findings confirm Eraut's observation that drawing upon practice-based experience is an important part of the skill of the experienced worker. Lastly the ability to handle non-routine situations is one of the key elements of professional knowledge, according to Eraut and this is something which we found in most of our interviews. This acceptance that many situations can be solved in multiple ways and the practice of considering the best alternative before deciding upon the action to be taken, was so common in our cases, that it was considered a normal part of everyday work, considered so normal that they were barely aware of it. Indeed, this match between Eraut's descriptions of professionals and the cases discussed in this paper, leads us to wonder if many of Eraut's professionals were perhaps also over 50 .

These ways of describing adult competence and learning in the workplace go a long way in explaining our main findings however, we have not found an accepted concept which includes some of the wider aspects we have observed as an important part of being an older worker. The kind of competence identified in the cases in the current study is similar in many ways to earlier research. However, our focus on age has provided us with examples which exhibit particular aspects of knowledge and our analysis suggests that they demonstrate related, but more nuanced examples than earlier research. In our analysis we used the idea of age or maturity to explain some of the findings, we will now elaborate on this.

Older workers have knowledge and competence necessary to do their job. They have the advantage of experience, which strengthens their ability to take decisions, reflect on alternatives, inspire colleagues and perform their job in cooperation with others. They have learned and developed ways to do their job that allow them to act with less preparation and almost without conscious thoughts. They know how to do their work without having to think about how they know it. In addition, 
they use their age and maturity to achieve results and interact successfully with others, such as colleagues, managers or the recipients of the services the workplace provides. They are more than competent old workers; they are what we define as wise workers.

Wisdom is often connected to old age. "Old and wise", as the saying goes. Edmondson (2015) discusses how "the idea of wisdom was seen as offering a goal for developing and changing during the lifecourse that was independent of direct involvement in types of work that depended on physical fitness" (2015: 156). This reminds us of our interviewees who talked about "working smarter, not harder". In a different project (Hilsen \& Strand, 2006) a kindergarten director talked about women in their 60s still working with the children. As she described it (in personal communication): "They don't climb trees as well as their younger colleagues, but they can talk the children down from the trees". Using experience and competence to do the job in spite of possible physical limitations can also be seen as an aspect of wisdom.

Although there is no generally accepted definition of wisdom, Edmondson (2015: 164) sorts theories of wisdom according to whether there is a tolerance of lack of perfection or not, and whether wisdom is seen as interpersonal as opposed to exclusively individual or not. According to this model of discriminating among theories of wisdom, there are "distinctions between wisdom envisaged as an extraordinary perfection and in more attainable versions, or between wisdom as reached in isolation and wisdom reached in some form of connection with others" (ibid.). We would place our wise workers in the lower perfection quadrant, in Edmondson's model, i.e. they can be described as wise without having achieved perfection in their demonstration of wisdom. We would also define wisdom of the wise worker as interpersonal, that is related to social interaction with others.

Another distinction in theories of wisdom is between those who see wisdom as a set of skills, wisdom as expertise (Baltes and colleagues referred to as the Berlin Wisdom Paradigm) and those that see wisdom as a particular personal characteristic (Ardelt, 2004; Baltes \& Staudinger, 2000; Edmondson, 2015; Gugerell \& Riffert, 2012).

The Berlin Wisdom Paradigm sets out criteria that define wisdom as a type of expertise. "Probably most important for a clarification of the explicit definitions are the five criteria of wisdom-related knowledge: (a) rich factual knowledge, (b) rich procedural knowledge, (c) life span contextualism, (d) relativism, and (e) uncertainty" (Gugerell \& Riffert, 
2012: 227-228). While the first two criteria are "characteristic of all types of expertise and stem from the tradition of research in expertise" (Baltes \& Staudinger, 2000: 125), the latter three are "meta-criteria that in their separate and joint expression, we consider specific for wisdom" (ibid.).

On the other hand, Ardelt defines wisdom as a composite of cognitive, reflective and affective qualities (Ardelt, 1997: 15). She argues that the cognitive dimension of wisdom refers to the cognitive ability to see truth as it is, not clouded by wishes and desires. While this element is important, it depends on the reflective component of wisdom, that allows us to reflect on what we see without being influenced by subjectivity and projections. Lastly, she argues for the affective component of wisdom, making the person able to develop compassion for others. As described: "Having overcome all their projections, reduced their self-centeredness, and gained a deeper insight into their own and others' motives and behavior, they are able to develop feelings of genuine empathy, sympathy, and compassion for others" (Ardelt, 2000: 361). In several studies (Ardelt, 1997, 2000) she explores how this wisdom depends on social and psychological resources and assets early in life, and finds that wisdom predicts life satisfaction in old age.

As we see from the above discussion, some of the literature on wisdom and old age seem to see meaning and wisdom as an individual coping with life at an existential level, while others focus on wisdom as a set of skills, what we can call contextual wisdom, wisdom as performance of wisdom in settings, such as worklife. In our understanding of wisdom, we do not reject the understanding of wisdom as a result of individual coping with life. Our wise workers demonstrate life wisdom, in their stories of acceptance of their stage in life, compassion for younger colleagues and willingness to share their knowledge. When they talk about being more tolerant as grandmothers than they were as mothers, this reflects their individual journey through life. In many ways this reminds us of Erik Erikson's description of human development stages from infancy to end of life (Erikson, 1963), where his eighth, as last, stage covers the age from around 65 years. This phase has the goal of attaining ego integrity, described as "realising the continuity in one's own personality and one's meaning for others" (Edmondson, 2015: 39). The basic virtue resulting from successfully achieving ego integrity, according to Erikson, is wisdom (McLeod, 2018).

At the same time our main focus is on how this wisdom is expressed in the way they talk about and perform their work. The wise worker is wise 
from a long work career, learning and reflecting on work, as they perform their everyday activities in the workplace.

A different take on the discussion of wisdom and ageing can be found with the American philosopher Martha Nussbaum. Nussbaum (2011) has developed theory of justice and entitlement for humans that define and compare quality of life at both individual and societal level, expressed through ten central capabilities. This theory combines individual conditions with societal conditions, and thus bridges the gap between the individual and the society in which the individual lives. Quality of life in old age (and being able to live to an old age) is covered in several of these capabilities. “... a decent political order must secure to all citizens at least a threshold level of these ten Central Capabilities:

1. Life. Being able to live to the end of a human life of normal length; not dying prematurely, or before one's life is so reduced as to be not worth living.

2. Bodily Health. Being able to have good health, including reproductive health; to be adequately nourished; to have adequate shelter.

3. Bodily Integrity. Being able to move freely from place to place; to be secure against violent assault, including sexual assault and domestic violence; having opportunities for sexual satisfaction and for choice in matters of reproduction.

4. Senses, Imagination, and Thought. Being able to use the senses, to imagine, think, and reason-and to do these things in a "truly human" way, a way informed and cultivated by an adequate education, including, but by no means limited to, literacy and basic mathematical and scientific training. Being able to use imagination and thought in connection with experiencing and producing works and events of one's own choice, religious, literary, musical, and so forth. Being able to use one's mind in ways protected by guarantees of freedom of expression with respect to both political and artistic speech, and freedom of religious exercise. Being able to have pleasurable experiences and to avoid non-beneficial pain.

5. Emotions. Being able to have attachments to things and people outside ourselves; to love those who love and care for us, to grieve at their absence; in general, to love, to grieve, to experience longing, gratitude, and justified anger. Not having one's emotional 
development blighted by fear and anxiety. (Supporting this capability means supporting forms of human association that can be shown to be crucial in their development.)

6. Practical Reason. Being able to form a conception of the good and to engage in critical reflection about the planning of one's life. (This entails protection for the liberty of conscience and religious observance.)

7. Affiliation. (A) Being able to live with and toward others, to recognize and show concern for other humans, to engage in various forms of social interaction; to be able to imagine the situation of another. (Protecting this capability means protecting institutions that constitute and nourish such forms of affiliation, and also protecting the freedom of assembly and political speech.) (B) Having the social bases of self-respect and non-humiliation; being able to be treated as a dignified being whose worth is equal to that of others. This entails provisions of non-discrimination on the basis of race, sex, sexual orientation, ethnicity, caste, religion, national origin and species.

8. Other Species. Being able to live with concern for and in relation to animals, plants, and the world of nature.

9. Play. Being able to laugh, to play, to enjoy recreational activities.

10. Control over one's Environment. (A) Political. Being able to participate effectively in political choices that govern one's life; having the right of political participation, protections of free speech and association. (B) Material. Being able to hold property (both land and movable goods), and having property rights on an equal basis with others; having the right to seek employment on an equal basis with others; having the freedom from unwarranted search and seizure. In work, being able to work as a human, exercising practical reason and entering into meaningful relationships of mutual recognition with other workers" (Nussbaum, 2011: 33-34).

Our mature workers live a long life with health sufficient to work. They express positive and-sometimes-negative emotions and affiliation towards their co-workers and the users of their services. Wisdom is developed through relationships with others during a long career, and practical reason is expressed in critical reflection about their work and life.

On the individual level, the central capabilities (ibid.) describe a level of quality of life that we recognize in the stories from our interviewees. 
As described in our cases, they have lived and learned through a long working career, and this achieved wisdom is expressed in their descriptions of how they perform their job in connection to and in relationship with co-workers and users of the services.

By adding a discussion on wisdom to our discussion of the kind of competence which our older employees have, we move beyond conventional understandings of competence. Our wise worker is competent in the ways we have described, but they have also lived a long life and aged, like a good wine. They have mellowed with age, and they exemplify this by referring to personal characteristics, like being more tolerant and accepting of others than when they were younger. They have learned to accept that we all make mistakes sometimes, and how to go on in spite of mistakes. They belong to a generation that shares cultural and political references and can relate to others through such shared references. These additional sides to senior competence, which are not normally defined as competence, make us look for a broader concept, and the literature on wisdom emboldened us to include these additional characteristics and define our workers as wise workers. Whereas the literature on wisdom often relates its discussions to the field of psychology and philosophy, we were inspired by the concept of wisdom to enrich our discussion on senior competence in the workplace. We understand wisdom to be a wider concept than competence when describing our older workers.

The wise worker is a mature, older worker who uses their age and many years of experience in working life to do their job in a way that benefits themselves, their co-workers and the organisation where they work. They are wise workers. We summarise the qualities of the wise worker in the following list:

\section{The Wise Worker}

Knows how (exactly how)

Knows who

Remembers why

Is a translator and bridge builder

Creates a safe environment

Embodies authority

Shares knowledge

Carries organisational history

Is selective 


\section{REFERENCES}

Aasheim, C., Shropshire, J., Li, L., \& Kadlec, C. (2012). Knowledge and skill requirements for entry-level IT workers: A longitudinal study. J Info Syst Edu, $23(2), 193$.

Antonacopoulou, E. (2006). Modes of knowing in practice: The relationship between knowledge and learning revisited. In B. Renzl, K. Matzler, \& H. Hinterhuber (Eds.), The future of knowledge management. Palgrave Macmillan.

Ardelt, M. (1997). Wisdom and life satisfaction in old age. Journal of Gerontology, Psychological Sciences, 52B(1), 15-27.

Ardelt, M. (2000). Antecedents and effects of wisdom in old age. In Research on aging, 22(4 July 2000), 360-394.

Ardelt, M. (2004). Wisdom as expert knowledge system: A critical review of a contemporary operationalization of an ancient concept. Human Development, 47(5), 257-285. https://doi.org/10.1159/000079154.

Baltes, P. B., \& Staudinger, U. (2000). Wisdom: A metaheuristic (pragmatic) to orchestrate mind and virtue toward excellence. American Psychologist, 55(1), $122-136$.

Edmondson, R. (2015). Ageing, insight and wisdom: Meaning and practice across the lifecourse. Policy Press.

Eraut, M. (1994). Developing professional knowledge and competence.

Eraut, M. (2000). Non-formal learning and professional knowledge at work. British Journal of Educational Psychology, 70(Pt 1)(1), 113-136.

Erikson, E. H. (1963). Childhood and society. Norton.

Gugerell, S., \& Riffert, F. (2012). On defining "Wisdom": Baltes, Ardelt, Ryan, and Whitehead. Interchange, 42/3, 225-259, 2011. Springer 2012. https://evidencebasedwisdom.com/2015/09/20/the-berlin-wisdomparadigm-an-expert-knowledge-system/.

Hilsen, A. I., \& Strand, B. E. (Eds.). (2006). Fortellinger om å få det til. AFIpublikasjoner. Arbeidsforskningsinstituttet.

Lundvall, B. A. (1996). The Social Dimension of the Learning Economy. DRUID Working Papers 96-1, DRUID, Copenhagen Business School, Department of Industrial Economics and Strategy/Aalborg University, Department of Business Studies.

Lundvall, B.-Å., \& Johnson, B. (1994). The learning economy. Journal of Industry Studies, 1, Nr., 2, 23-42.

McLeod, S. A. (2018, May 3). Erik Erikson's stages of psychosocial development. Simply Psychology. https://www.simplypsychology.org/Erik-Erikson.html.

Nussbaum, M. (2011). Creating capabilities: The human development approach (pp. 33-34). Harvard University Press. 
Open Access This chapter is licensed under the terms of the Creative Commons Attribution 4.0 International License (http://creativecommons.org/licenses/ by $/ 4.0 /$ ), which permits use, sharing, adaptation, distribution and reproduction in any medium or format, as long as you give appropriate credit to the original author(s) and the source, provide a link to the Creative Commons license and indicate if changes were made.

The images or other third party material in this chapter are included in the chapter's Creative Commons license, unless indicated otherwise in a credit line to the material. If material is not included in the chapter's Creative Commons license and your intended use is not permitted by statutory regulation or exceeds the permitted use, you will need to obtain permission directly from the copyright holder.

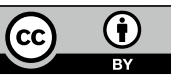

